\title{
Huerta al alba
}

Carlomagno Sol Tlachi Universidad Veracruzana

Resumen

Efraín Huerta nació en Silao, Guanajuato, en 1914, y murió en el D. F. en 1982. En este año 2014, se cumplen setenta años de la aparición de Los hombres del alba. Si la generación Contemporáneos marca el antes y el después de la poesía mexicana actual, Huerta, con la edición de su libro en 1944, es un referente obligado si se pretende llegar al lugar de donde es oriunda la poesía moderna y contemporánea mexicana. A partir del contexto ideológico que le toca vivir al poeta guanajuatense en la capital, que dejó huella profunda en sus primeros libros, se pone en relieve el giro de 180 grados que, después de aquella primera etapa, dieron los poemas que constituyen Los hombres del alba a la poesía mexicana.

Palabras clave: México, poesía moderna mexicana, Contemporáneos, vanguardia, Efraín Huerta, revistas literarias, realismo socialista.

Abstract

Efrain Huerta was born in Silao, Guanajuato, México, in 1914. He died in Mexico City in 1982. This year (2014) is the 70th anniversary of the apparition of Los hombres del alba. If the Contemporáneos generation marks a before and after of the current Mexican poetry, then Huerta, with the publication of his book in 1944, is a obligatory point of reference in order to arrive to where modern and 
contemporary Mexican poetry hails. The ideological context, in which this poet lived in the capital city, marked his first books. Moreover, it is emphasized the 180 degrees turn that, after this first stage, the poems that constitute Los hombres del alba gave to Mexican poetry.

Keywords: Mexico, Modern poetry, Contemporáneos, Avant-gard, Efrain Huerta, Literary reviews, Socialist realism.

$\mathrm{C}^{1}$ páramo por ser páramo no nos es desconocido entre la poesía de Tablada-López Velarde y la de los Contemporáneos; aún predominaba la presencia de Enrique González Martínez y, a pesar de que no había una nueva y fuerte expresión mexicana "a la altura del arte", ya se preparaban nuevas generaciones de poetas en México. Por otra parte, es lugar común señalar, como seminario de las generaciones de escritores, los cenáculos agrupados a las publicaciones periódicas; el contexto donde surge Efraín Huerta no podía ser la excepción.

Si el modernismo fue el surco que haría germinar una semilla nueva en las letras mexicanas, los Contemporáneos fueron quienes hicieron una escisión entre el antes y el después de la actual poesía mexicana. El cisma perpetrado por los Contemporáneos, que tuvo efecto directamente en la poesía de mediados del siglo XX, en franca ruptura con la poesía del siglo XIX, de acuerdo a lo dicho, no podría pasar desapercibida en la obra de Efraín Huerta. El eco que logramos escuchar de los Contemporáneos es el de una plena avanzada que intenta colocar una estética mexicana en el ámbito universal. La voz del ideólogo de los Contemporáneos expresa: “El nacionalismo mexicano se ha caracterizado por su falta de originalidad, o, en otras palabras, lo más extranjero, lo más falsamente mexicano que se ha producido en nuestro arte y nuestra literatura, son las obras nacionalistas" (Cuesta, 1994: 23). 
Al mirar hacia atrás, el camino tenía antecedentes desde la publicación de la Revista Azul hasta llegar a la poesía de López Velarde. Con la continuidad de la Revista Azul en la Revista Moderna (1898-1911), el modernismo da solidez a sus postulados: "ruptura del encierro de siglos, fantasía, pasión, imaginación, placer verbal, erotismo, ironía, conciencia crítica del lenguaje, exploración del inconsciente" (Pacheco, 1979: XVIII). Si el modernismo deseaba colocar la voz en la tesitura de la poesía europea el fracaso estaba garantizado, desde el punto de vista del mosaico de lo que pudo haberse considerado como lo nacional, y si continuaba en lo que incluso López Velarde ya había superado. ${ }^{1}$ Respecto de éste y las generaciones de lectores posteriores a él, muy bien lo advirtieron, por ejemplo, aquellos jóvenes estudiantes de preparatoria (Luis Enrique Erro, Octavio G. Barreda, Guillermo Dávila y Fernando Velázquez Subirinski) que publicaron la revista San-ev-ank, donde dicen sobre López Velarde:

${ }^{1}$ Probablemente los Contemporáneos lo vieron así: Tablada ve a su generación hundida en un pantano que los mancha a todos. En 1914 el símbolo modernista ya no es el cisne heráldico sino el humilde pijije, con "el ala inválida y herida / que ya no habrá de volar nunca”. Entonces Tablada emprende otro exilio y otra aventura. Sus haikús inician para México la vanguardia mientras un siglo de tentativas culmina en la obra de Ramón López Velarde, "Y si es cierto —escribió Octavio Paz en 1951 - que no es posible regresar a la poesía de López Velarde, también lo es que ese regreso es imposible precisamente porque ella constituye nuestro único punto de partida” (Pacheco, 1979: XIX). Lo que estaba más que visto es que el encasillamiento "poeta de la provincia» que se hizo de López Velarde, lo agotaron Francisco González de León y el padre Plasencia; de ahí la reacción inminente de los Contemporáneos. Posteriormente, más que el grupo Contemporáneos, la poesía de Efraín Huerta se yergue desde la ruptura total. Semejante al realismo, los andamios de la poética de Huerta son la experiencia social vuelta poesía, es la voz colérica de quien no está conforme con una realidad emanada de la sociedad misma, compuesta por la insensatez y la mediocridad de la vida urbana anodina. 
No es atributo de la juventud, como presuntuosamente opinaron «Sub-y-baja» en las columnas de San-ev-ank, juzgar a los poetas que, como López Velarde, pasaron ya el periodo de gestación y han entrado al de la madurez. López Velarde es un poeta, entre nosotros, raro, penetrado eso sí hasta lo más hondo de la tenaz influencia de El lunario sentimental. Para juzgarlo son necesarias una límpida serenidad de espíritu y una percepción finísima y clara, muy difíciles de obtener a los veinte años (Martínez, 1994: 80).

Si se continua con el señalado lugar común que consiste en asociar el surgimiento de la mayoría de las generaciones literarias mexicanas con las publicaciones periódicas, el contexto de éstas con respecto a Efraín Huerta lo forman Taller Poético, Barandal, Cuadernos del Valle de México, Tierra Nueva y la transformación de Taller Poético en la revista Taller en 1938. Le anteceden, hacia la década de los veintes, La Falange, editada por Jaime Torres Bodet y Bernardo Ortiz de Montellano, y, por supuesto, Contemporáneos.

En 1936, aparece la revista Taller Poético. Su editor, Rafael Solana, tiene como intención publicar ecuménicamente a los poetas del momento (no sólo los radicados en la capital sino también a los de la provincia) que ya poseían un lugar en las letras mexicanas. Fueron cuatro números antes de que su existencia terminara en 1938.

En este contexto, la ubicación de Efraín Huerta a principios del siglo XX, necesariamente obliga a relacionarlo (amén del fenómeno apuntado respecto de las publicaciones periódicas) con Octavio Paz. Así, históricamente la trayectoria poética de Huerta se podría alinear más o menos de forma paralela al trabajo editorial que hizo Paz.

La articulación entre los Contemporáneos y Paz fue la publicación de la revista Barandal (1931-1932), dirigida por el propio Octavio, Rafael López Malo (hijo de Rafael López, sobreviviente del modernismo y amigo de López Velarde), Arnulfo Martínez La- 
valle y Salvador Toscano. En el número seis de la revista, Villaurrutia publica "Dos nocturnos"; Octavio Paz señala: "En el último número de Contemporáneos se dice que finalmente ha surgido una nueva generación literaria, que es la generación agrupada en $B a-$ randal. De modo que el bautizo literario de Barandal coincidió con el acta de defunción de Contemporáneos" (apud. Ylizarriturri, 1999). Para ese entonces, Rafael Solana editaba la revista Taller Poético, donde participaba Efraín Huerta. Paz sintetiza este periodo:

Dentro de cada generación hay muchas tendencias, distintos grupos y personalidades, choques. Nosotros éramos entonces los mayores, los que sucedíamos a los Contemporáneos. Detrás venía otro grupo que descubrí un poco después, entre los que sobresalía un joven poeta, Efraín Huerta. Yo era estudiante de la facultad y él de último año de preparatoria, en San Ildefonso. Entre ellos también se encontraban Rafael Solana y otros más, que habían fundado Taller Poético (apud. Ylizarriturri, 1999).

Aún estaría Paz al frente de la aparición de Cuadernos del Valle de México (1933-1934) antes de que las líneas paralelas convergieran en el encuentro de la generación llamada Taller; también estaría de por medio el lapso en que a Paz experimenta de primera mano la guerra civil española. A su regreso, Solana le propone transformar Taller Poético en simplemente Taller. El primer número aparece en diciembre de 1938; Solana sufraga los gastos de este número y luego se desentiende.

Como se dijo, con mucha anticipación a la generación de la revista Taller, los Contemporáneos tenían la firme convicción de que el camino para poner a la altura del arte poético europeo a la poesía mexicana no era mediante el nacionalismo, así como tampoco era por medio del compromiso social al servicio de la ideología marxista; la cual, había llegado a los límites extremos en que el 
"sarampión marxista” provocaba actitudes como "En México, ser escritor comprometido consiste en exigirles a los demás que sean escritores comprometidos" (Batis, apud Flores, 1981: 38).

Aquí valdría la pena relacionar la sólida influencia que tuvo la revolución rusa en el pensamiento intelectual tal y como lo tuvo la revolución francesa en los escritores románticos, por ejemplo, alemanes. Se trata del entusiasmo que representa la esperanza del cambio, uno que pueda desarrollar las condiciones sociales con mejores oportunidades para todos. México no podía ser la excepción. Muchos creyeron ver en el socialismo marxista la emancipación de las clases sociales; otros, más prácticos o escépticos, depositaron su perspectiva en un horizonte más allá de la efervescencia del momento. ${ }^{2}$ Octavio Paz, al igual que Villaurrutia, creía que las vías de emancipación del hombre se hallaban en latitudes distintas a las del socialismo marxista:

el joven ensayista se rehusaba a supeditar la poesía al ideal social. Más tarde, al conocer la obra de Luis Cernuda, Paz descubriría una forma más sutil de rebelión que, más allá de la transformación social, alcanzaba la naturaleza humana. Al leer La realidady el deseo, comenta:

... escuchaba una voz profundamente individual, en la cual la subversión moral se unía a la subversión poética y era imposible identificar a la revolución social con la subversión. El poeta iba más allá, traspasaba, diríamos, la lucha revolucionaria y me mostraba otro mundo (Flores, 1991: 138-139).

Huerta fue de los primeros. Para aquel entonces escribió poemas como "Stalingrado en pie", "Los soviéticos" y "URSS". Los ecos

2 “"[Villaurrutia] sentía una invencible desconfianza ante todas las teorías, los sistemas y las escuelas...' razón por la cual habría descartado la rebelión social y explorado dominios más individuales". En Octavio Paz, Xavier Villaurrutia, Antologia, pp. 16-17. (apud Flores, 2008: 144) 
del romanticismo social, resultado del primer socialismo, se dejan ver como un reflejo de aquellos utopistas franceses (Saint-Simon y Charles Fourier) que veían la armonía social en un falansterio. El socialismo es la ideología que tenía como misión liberar del yugo al hombre por el hombre, lo cual resultaba en una sociedad sin clases.

$\mathrm{Si}$, por una parte, la pléyade de intelectuales que participó activamente en la adaptación del realismo socialista en México fue un grupo bastante grueso; por otra parte, hubo otro sector que pudo inmunizarse a tiempo del virus marxista, llevando a extremos la escritura poética. Tal fue el caso del efímero y desconocido "Poeticismo" cuyo registro tiene significado al evocar las circunstancias relacionadas con la izquierda mexicana. Eduardo Lizalde explica:

Los poeticistas éramos, inicialmente, desde 1948, el que escribe y Enrique González Rojo, que navegábamos con natural petulancia por el kindergarten del mundo literario bajo la mirada paternal del poeta Enrique González Martínez (abuelo de aquél), que andaba cerca de los ochenta años y toleraba, estupefacto pero cordial y animoso, todas las atrocidades teóricas y líricas de las creaciones poeticistas (Lizalde, 1981: 14).

Más tarde, en 1951, se incorpora efímeramente Marco Antonio Montes de Oca quien, hacia 1953, comienza a dar visos de independencia respecto del grupo poeticista con la publicación de "Ruina de la infame Babilonia" en la revista estudiantil de la Facultad de Derecho, editada por Carlos Fuentes, Porfirio Muñoz Ledo, González Cosío, entre otros. A partir de ahí, comenzó a publicar "poemas mucho más legibles y decorosos" (1981: 18), a decir de Lizalde, quien compara los suyos y los de González Rojo con los de Montes de Oca.

En la Autobiografía de un fracaso; el poeticismo, Eduardo Lizalde, como dejar ver en el título, se propone denostar lo que fue y significó algo que pretendía ser un movimiento poético, ya que según 
él no fue otra cosa más que un intento pasmosamente fallido; ${ }^{3}$ sin embargo, lo que puede apreciarse en el abono a la historiografía de la lírica mexicana es que (tal y como sucedió con experimentos, también efímeros, como el de los Estridentistas) de alguna manera contribuyó a la construcción de la poesía mexicana.

Lo que aquí interesa no es precisamente la importancia que tuvo o no el poeticismo de Lizalde, González Rojo y Montes de Oca, sino la liga ideológica y contextual del momento en México, que vive la efervescencia del marxismo (donde la izquierda era "más papista que el papa”), y el condicionamiento que envolvía a las actividades intelectuales y artísticas. Tómese en cuenta, como ejemplo, el apartado "Sarampión marxista y treintena trágica" del libro arriba mencionado.

Totalizar y etiquetar son dos de las conductas características de la vida social. De ahí se desprende, en gran medida, la forja del espíritu de época. A Efraín Huerta le tocó un momento en que la agitación comunista en México estaba muy arraigada en el contexto intelectual. Octavio Paz recién regresaba de Espańa, Bretón se entrevista con Trotski en la casa de Diego Rivera y, en 1950, Neruda visitaba a Enrique González Martínez en su viaje a México para asistir al Congreso Internacional de la Paz, desde cuya tribuna excomulgaría al disidente José Revueltas. ${ }^{4}$ En un momento en que el realismo socialista era la panacea del momento, Huerta participa activamente, lo cual queda manifiesto en la permeabilidad que ofrece su obra poética y el interés en sus primeros años como escritor. Debido a ello, en la posteridad, no queda exento de la acción

${ }^{3}$ Incluso, yendo poco más allá de la presencia del poeticismo, dice Lizalde: "mi espantoso primer libro de 1956 (La mala hora), [...] no era ya sino un degradado híbrido de poeticismo vergonzante y escolar marxismo" (Lizalde, 1981: 15). 4 "a quien acusó de existencialista y reaccionario por la publicación de Los días terrenales. Neruda no había leído la novela, pero lo asesoraban todos los sectarios mexicanos de la época, que ya habían hecho una campaña periodística contra el joven escritor" (Lizalde, 1981: 49). 
descalificadora. A la poesía de Huerta de este periodo se le ha dado la categoría de panfletaria, como si la parte más representativa de su obra fuese la poética social o como si el horizonte que la motivaba no fuera de los más caros a las perspectivas humanistas, en tanto que trata la emancipación social y solidaridad humana. En este periodo tuvo su auge la producción poética de Huerta, aunque muy pronto el guanajuatense pudo darse cuenta de que las luchas sociales de grandes magnitudes tienden al desencuentro, ya sea debido a que los seres humanos tenemos intereses disímiles, o bien a que somos inestables y tendemos hacia la búsqueda constante de la diferencia. El virus comenzó a corroer desde dentro: el realismo socialista fue una panacea que llevó a extremos el catecismo que debía profesar el arte.

Efraín Huerta se ubica en el extremo opuesto a Villaurrutia, pues es innegable que tuvo una época real-socialista durante la cual mostró una fe ciega en las promesas del proyecto comunista. Sin embargo, su entusiasmo se debilitaría a medida que las contradicciones del régimen, ocultas tras el brillo de la propaganda, se manifestaran tanto en las naciones «liberadas» por el Ejército Rojo, como en la misma URSS.

Al final de un periodo de dogmatismo, Huerta abandona el arte comprometido para reencontrar el vasto horizonte de la poesía sin preceptiva, que había quedado latente en Los hombres del alba. Si acaso se insistiera en el término "contenido social» para calificar este periodo de su obra, sería porque Huerta no abandonó nunca su posición de testigo y de conciencia de su sociedad, de su tiempo. En este sentido, "contenido social» sería más explícito si viniera acompañado de sustantivos como solidaridad o fraternidad (Flores, 2008: 144).

No es que se trate, la de Huerta, de una actitud inestable, que por el desencanto originado por las circunstancias se olvidara del compromiso o misión social del ser humano y, en este caso, del 
poeta. Con la conciencia muy clara de lo que sucedía en la Rusia socialista, cambia su actitud hacia las circunstancias del momento, mas no su anhelada fe en la igualdad, justicia y libertad humana.

[...] es fácil rastrear un compromiso permanente [de Efraín Huerta] con su tiempo, que va más allá de esta etapa; escribió poemas para cada uno de los eventos mayores de la historia del siglo XX: la Revolución Rusa, la Revolución China, la Guerra Civil Española, la Segunda Guerra Mundial. En el caso de México, dedicó al menos un texto a la Revolución Mexicana, a los movimientos sindicales, a las represiones de 1968 y de 1971 (Flores, 2008: 138).

En este 2014, se cumplen setenta años de la publicación Los hombres del alba. 5 Se ha dicho que este poemario es el más representativo de Efraín Huerta, aunque quizás no lo sea de su obra total porque reúne, en 1944, la poesía anterior, la que va de 1930 a 1944, o porque dialécticamente está antes que otros de sus libros. Independientemente de que sea el más representativo o no, el valor alcanzado por Los hombres del alba no recae únicamente en el

${ }^{5}$ Efraín Huerta estudió derecho y se dedicó al periodismo. Junto con Octavio Paz y Rafael Solana, entre otros, editó la revista Taller (1938-1941), la cual da nombre a la generación que se formó en torno a la publicación. La ficha de la edición aquí comentada es: Los hombres del alba, prólogo de Rafael Solana, México: Géminis, 1944, 193 pp. Contiene: "Los ruidos del alba" I-II, "La lección más amplia", "La poesía enemiga", "Verdaderamente" I-III, "Línea del alba" I-VIII, "Teoría del olvido" I-V, "Precursora del alba", "Recuerdo del amor", "El amor", "Primer canto de abandono" 1-3, "Segundo canto de abandono", "Tercer canto de abandono"; Declaraciones: "Declaración de odio", "Declaración de amor" 1-2, "Los hombres del alba", "La muchacha ebria", "Tu corazón, penumbra", "Cuarto canto de abandono", "Problema del alma" I-V, "Esta región de ruina" I-II, "Poema del desprecio" I-VI. Acompaña a la edición, en la anteportadilla, un autorretrato a línea. Al final de la penúltima estrofa del "Segundo canto de abandono", el verso final ("hacerse luz de fuego en el espectro") ha sido agregado de puño y letra del autor. 
ámbito de la obra poética de Huerta: es un libro muy importante dentro de la historiografía de la poesía mexicana.

Para la fecha en que se publica este poemario, su poesía tenía ya bastante fuerza; había nobleza y calidad pues Huerta ya había logrado dar a su poesía la definición de lo que sería la voz y el estilo que lo harían figurar como uno de los poetas más representativos para las generaciones posteriores de jóvenes, que no sólo lo leían, sino que también imitaban su estilo.

La edición de entonces la acompańa un prólogo de Rafael Solana, quien refleja un conocimiento experto de la trayectoria poética de Huerta. En términos generales, hay un planteamiento que tiene que ver con la discusión de si el arte debe ser bello o no. Inicia su reseña con la explicación en torno a que hay arte "agradable" y arte "desagradable", pero es, al fin, arte. Solana dice: "Las poesías de Efraín Huerta son sumamente desagradables"; no obstante, inmediatamente, agrega: "y cuentan en primera fila entre las mejores que se han escrito en México” (Solana, 1944: 9). Ha quedado muy atrás la querella de que la belleza (el didactismo o la moralina) sea un factor determinante para que haya arte. Nos hallamos ante el hecho de que las exigencias van más allá de lo pegajoso o halagador, incluso aún más allá de lo accesorio como la rima o el metro, ${ }^{6}$ para llegar a un espacio donde lo desagradable resulta estético, donde la poética de lo desagradable es el antídoto determinante en contra de "la vulgaridad y a la pobreza de espíritu de lo fácilmente aprehensible" (Solana, 1944: 9).

Si acaso habría que sentirse tentado por hacer alguna totalización de la poesía de Huerta, podría decirse que, lo que ha perdurado de su obra, ha sido una poesía sin preceptiva, en contraposición

6 "Las palabras no son utilizadas nunca en función de sus valores fonéticos, rítmicos, del número de sus sílabas, las características de su tónica, la riqueza de su colorido sonoro, sino exclusivamente son estimadas como fórmulas de sugestión de ideas, en aspectos rígidamente semánticos" (Solana, 1944: 11). 
a su obra enmarcada por la ideología real-socialista cuya atmósfera emanaba de la fe ciega en las promesas del proyecto comunista. Afortunadamente, hacia 1952, el poeta da muestras de un desligamiento con relación a la preceptiva del arte social.

Las inconsistencias de la poesía comprometida residen en una interpretación perversa, que concierne a la naturaleza de la actividad poética. La poesía es una experiencia «ahistórica» o "antihistórica», pues a pesar de que tiene lugar en la historia, su materia son las experiencias fundamentales de la vida del hombre —el amor, la muerte...-, experiencias que al repetirse contradicen el paso del tiempo. La poesía escapa a la sujeción de la historia; los poemas son «máquinas productoras de tiempo que continuamente regresan a su origen, máquinas antihistóricas». Por este hecho, el poema se alejará naturalmente de la coyuntura que parece arraigarlo al suceder cronológico para ubicarse en un nivel superior (Paz, apud Flores, 2008: 145-146).

Cuando William Carlos Williams escribe The spring at all, da inicio la poesía moderna norteamericana; por ejemplo, "the red wheel barrow" (sin puntuación, sin rima y sin metro) es un poema que marca una nueva generación en la poética del siglo XX, generación que hará la diferencia al dar inicio a nuevos derroteros para la lírica norteamericana, como la generación de poetas agrupados al clisé "poesía desnuda". En México, la poesía de Huerta se expresa sin

${ }^{7}$ Se reconoce como "poesía desnuda" la lírica norteamericana de vanguardia (poetas nacidos entre 1925 y 1935 que formaron movimientos como Black Mountain, the Beats o the New York Scool), cuya tendencia consiste despojarse de las formas líricas tradicionales y, en especial, la rima y la métrica. Aunque, a decir verdad, a pesar de que se trata de formas abiertas, no es la forma lo que realmente les interesaba: podría decirse que, dentro de la diversidad de poetas de esta generación, lo que los caracteriza son las estructuras que se desarrollan orgánicamente, de tal manera que es el significado el que determina la forma y la musicalidad del poema. Nada lejano a lo que nos ofrece Efraín Huerta. 
preceptiva, sin los artificios retóricos adicionales a la explotación semántica. En ella, se hallan las semillas que detentan el rechazo al Establishment cultural. A partir de la aparición de aquel libro de 1944, "aparece en el panorama literario una multitudinaria 'poesía bárbara' que logra en el público mayor influencia y prestigio que los poetas cultos. Decadencia de la tradición cultista y la apoteosis de una expresión desesperada y cruda constituyen los nervios estructurales de la poesía mexicana reciente” (Blanco, 1981: 215).

El interés por la forma ha adquirido un lugar irrelevante como respuesta al interés por lo que se dice; hay una especie de camuflage en el que la forma del poema es la simbiosis de las emociones y la forma o dialéctica de los pensamientos estructuran el poema; no obstante, sobre todo, priva la característica de que no hay necesidad de hermeneutas o iniciados. Se trata de una poesía que nos recuerda la pureza del lenguaje en expresión de la franca fe poética.

Desde el alba de su trayectoria poética, Efraín Huerta no hizo concesiones con su tiempo o con el pasado, hubo un destello de rechazo a lo establecido, al conservadurismo, a la comodidad o al afán de pertenecer servilmente a algún gremio o escuela poética. En su actitud hallamos la rebeldía de aquel que tiene la conciencia del desacuerdo en contra de la comodidad, del pensamiento obtuso y cerrado. Tal vez, aquí valga la pena señalar una de las diferencias entre el pensamiento burgués y conservador, pues éste se caracteriza por sus lacras mentales; de ahí surge el equívoco de señalar que si no se está de acuerdo con la ideología de izquierda, se está en contra de ella. La actitud de Octavio Paz puede ilustrar algo que ha privado mucho en el pensamiento libertario y que Paulo Freire encierra en su máxima ya conocida: "Nadie libera a nadie, cada quien se libera a sí mismo": "si me opuse al arte "engagé", al arte social y a todas esas cosas que por muchos ańos se escribieron en América Latina, fue porque a mí me parecía inmoral que un 
escritor asumiese que de su parte estaban la razón, la justicia o la historia" (Paz, apud Flores, 2008: 142).

Si de alguna manera se pudiera hacer tabula rasa del devenir de la cultura (la cultura por antonomasia) podría considerarse para ello un efecto físico de acción y reacción. La acción se establece por el establecimiento de lo que en su momento fue una reacción, llámense filosofías del underground ${ }^{8}$ o manifestaciones contraculturales. Algunas corrientes, escuelas, manifestaciones o movimientos han pasado a la posteridad sin mayores honores; otros han dejado una huella profunda, por lo que calaron el devenir de la cultura, $y$, otros, como el Romanticismo, lograron una permanencia a través de vástagos, que, aunque se registren de manera diferente al movimiento, no han sido otra cosa más que romanticismos: realismo, naturalismo, simbolismo, surrealismo, etcétera.

El canon como institucionalización de la acción ha pasado a representar lo que ha sido la conserva de la cultura. Es de lo que se ocupan en las universidades: promoción de la ausencia de "crítica" y el conservadurismo que provee estabilidad y, por tanto, comodidad y orden. No podría haber otra razón, pues no podría enseñarse lo que genera desequilibrios, libertad, autonomía e independencia ya que el anarquismo no le conviene al Estado, y la educación es la sierva del poder.

Una de las prácticas muy caras (se podría decir que se trata de una segunda naturaleza del ser humano) es la discriminación. No hay mayor práctica que caracterice a nuestra especie como la tendencia constante a la deslegitimación, la descalificación y la práctica de la diferencia; no es porque la diferencia sea espuria, pues es el fundamento de lo individual, sino que se practica la diferencia en términos de una superioridad que se antepone a la inferioridad; por lo tanto, en el sesgo que estamos abordando: todo aquello que anatematice lo establecido será descalificado.

${ }^{8}$ Vid. Luis Racionero, Filosofias del underground (1977). 
Con estas premisas, séame permitido hacer una aclaración: no estoy incurriendo en la falta que estoy señalando; finalmente, detrás de todo, lo que debe importarnos es el arte como aspiración más elevada del espíritu humano. Por otra parte, tomar como base el presente para trascender hacia el futuro es característica del arte en firme deseo por no querer ser (lo han dicho hasta el cansancio las teorías de los "choques generacionales") repetición y pasado, sino reacción; la anticipación del futuro. Por estos adelantos y retrocesos desde el presente, el hombre se determina como un ser histórico; necesita la conciencia de la tradición para fincar su presente y, con una profunda fe ciega, apuesta por "lo que podría ser", de lo cual únicamente la posteridad se encargará. La conciencia histórica y el presente son la base para aspirar trascender el futuro. Como se puede apreciar, inevitablemente se requiere de una plataforma: la reacción requiere del pasado, así como la serpiente que se muerde la cola, el presente debe construir su pasado para ser. El futuro del artista es el topus que da esencialidad al ser humano: a partir de la necesidad de comunicación, aspira en ésta llegar a su forma más pura: al significado poético.

La poesía de Efraín Huerta se singulariza por la disensión frente a lo establecido. Contra la contemplación que descubre los matices de lo inolvidable, no acepta más asombro que resolver su protesta con lenguaje frecuentemente «antipoético», mezclado con emoción nunca exenta de ternura. Dentro de estos dos extremos, fluctúan sus sentimientos, lo mismo cuando recuerda un deseo perdido que cuando invoca el recinto de la soledad. A sus manos, las formas llegan convertidas en pretextos para decidir que la quietud domina alrededor. Aun el alma, último refugio en que se acoge el inconforme, es emblema de zozobra, reino de las tinieblas por donde cruza la desesperación. Revolucionario a veces, siempre desesperado, Huerta no concede cuartel a su convicción de proyectar su protesta en todo lo que toca. Pero si en esto estriba su originalidad, también ha de observarse que su espíritu, así 
se muestre nutrido de violencia, se sustenta en un amor por sus semejantes que impregna toda su poesía (Pacheco en Paz: 1998, 240).

Inconforme, corrosivo, insólitamente sincero, Huerta es el ejemplo del ser humano romántico atemporal, pues fuera de lo que el Romanticismo fue como corriente, hay también una acepción para el romanticismo como un estado del alma y de la conciencia. Aunque no es lugar aquí para la exposición de la poética que como programa estético expusieron los hermanos Schlegel, quienes estaban al frente del círculo de Jena (punto de partida del Romanticismo alemán), baste con indicar que una renovación del ser humano como preocupación principal fue uno de los aspectos centrales de los románticos alemanes, sólo que ahora, a diferencia del proyecto renacentista, desde la preocupación de dar legitimidad a los procesos interiores de la conciencia. En la poesía de Huerta hallamos no la voz ajena, aquella que sin garbo ni empeño nombra el entorno ordinario directamente, sino la que revela el sí mismo, la que da cuenta de la interioridad y del ser que vive dentro; ahí está el brillo mágico para quien lee "La lección más amplia", "La poesía enemiga”, "La línea del alba”, "Precursora del alba”, "Recuerdo del amor"...

Por su parte, desde la publicación de Absoluto amor, Efraín Huerta inaugura, al menos, una línea de escritura propia. No resulta exagerado decir que desde ese momento, "aparece como un altísimo poeta, de grandes vuelos, de vigorosa personalidad, de exquisita pureza, de novedad sorprendente" (Solana, 1944: 9).

Los hombres del alba representa, dentro de la trayectoria poética de Efraín Huerta, la culminación de una etapa en la que el proceso que representó la escritura de poemas como "Los ruidos del alba" I y II, "La poesía enemiga", "Verdaderamente" I a III, "Línea del alba" I a VIII, "Precursora del alba", pasando por los cantos de abandono y las declaraciones hasta "Los hombres del 
alba" y "La muchacha ebria", marcaron un antes y un después en la lírica moderna mexicana. ¿Cuál era la novedad? Huerta ofrece una poesía en la que deposita un valor eminentemente semántico y deja para la tradición el ritmo encorsetado del metro. "En esta absoluta ignorancia de la musicalidad reside uno de los principios de ingratitud de esta poesía, ríspida, agria y desvertebrada, en su apariencia física, sensual; pero hay todavía más; también por lo que evocan, y no solamente por cómo suenan, esas palabras de que se forman los versos van creando estados de ánimo destemplados” (Solana, 1944: 11).

La poesía de Efraín Huerta creó una aguda disidencia en la trayectoria de la poesía mexicana, escisión que adquirió un cauce propio y significativo. Su poesía se despojó de las formas y estrategias de la poesía del momento. Estableció un arte poética cuya impronta quizás pudiera tener una lejana filiación con la poética del vate de Jerez.? Acudió al verso libre y a formas abiertas si se compara, por ejemplo, con las formas cultivadas por la poesía de los Contemporáneos. Hay pues en la poesía de Huerta una ausencia de la forma tradicional de la poesía, lo cual causó, por una parte, mucha incomodidad y, por otra parte, creó una gran cantidad de seguidores.

Es incalculable, pero sospecho que suman a varios cientos, la cantidad de jóvenes poetas que surgen en las escuelas preparatorias y superiores de provincia y de la capital, que en lugar de identificarse con las figuras literarias ejemplares (Borges, Paz, Lezama) se arraigan en la aterrada, semianalfabeta, sentimentalísima, irracio-

${ }^{9}$ Cuando López Velarde pareciera confiarnos al oído: "Mi madrina invitaba a mi prima Águeda / a que pasara el día con nosotros...”, el prosaísmo lírico hace su aparición en el terreno de la poesía. Y quizás no haya, hacia la primera mitad del siglo XX, quien llevara a extremos la trayectoria en el empleo de la lengua cotidiana, como soporte de la expresión poética, como Efraín Huerta; la cual, hacia las décadas de los treinta y los cuarenta no fue de la complacencia ni de la poesía ni de la crítica institucionalizada. 
nal y anti-intelectual vida urbana de la clase media en bancarrota y se asumen como los «menesterosos de la cultura», los «condenados de la tierra cultural» (Blanco, 1981: 215).

Es esa la identidad que proporciona la poesía recogida en Los hombres del alba. Se trata de una revuelta que viene a representar la necesaria presencia de la contracultura dispuesta a dar un revés a las formas canónicas establecidas. Se trata de una especie de poesía salvaje que se hermana, por ejemplo, con aquella corriente pictórica que rechaza el academicismo, en cuanto tal, que presenta el cuadro de factura impecable pero de contenido intrascendente; ofrece, en cambio, el salvajismo de los colores primarios directos, espacios en crudo en el lienzo, las alternativas de otros materiales no canónicos para obtener texturas novedosas, diferentes, desgarradoras o violentas. A este contexto, aludido al principio de este artículo, se refiere Solana. El Guernica no es bello, no es agradable; alude a una masacre, hay protesta y dolor.

Mediante procedimientos poco explorados, Huerta logra una expresión propia, inmaculada; como si fuera resultado de la invocación creativa obtiene la más pura y virginal poesía. No hay contaminación alguna, es sólo su voz, un canto que existe por sí mismo, es la inclinación humana por la búsqueda de la voz propia y, por tanto, la voz original de la creación poética. Los artificios que pudieran servir de anclaje para que la palabra sea poesía, han quedado relegados, y sólo así se ha podido dar paso a la expresión nueva, intacta.

Pongamos por ejemplo "Los ruidos del alba", una línea de lectura se construye con material del sueño; sueño y agonía comparten lazos de avecinamiento: el sueńo es la ausencia de vigilia, es una forma de anticipación de la muerte sin morir, como la agonía es una contienda en contra de la muerte. Rodean esta atmósfera murmullos, ruidos, el frío. Hay una especie de añoranza por el silencio, éste se aparta, es desplazado por la oscuridad (cielo sin 
estrellas) por nuestras bocas (las palabras, la voz, lo que es ruido). Los hombres han extraviado el alba, esa aurora, la superficie tierna; la juventud se ha perdido. Las percepciones completan la atmósfera del alba, la que tiene la piel como el agua blanca: rumor (oído), limones (olfato), ojos (vista).

La forma del desencuentro se patentiza a través de imágenes cuya expresión nace a partir del imperativo "Expliquemos al viento nuestros besos". No hay empresa humana que pueda hacerlo, todo afán queda relegado al mero intento; sin emgargo, vale la ilusión, "Piensa que el alba nos entiende". El desencuentro persiste, la imposibilidad que se lee entre líneas al señalar la presencia del alba, los trozos de nieve, el frío invicto como invicta es la juventud (la gran llama de oro, los diecinueve años, la adolescencia, cristal murmullo de madera blanca incendiada). Hay una persistencia del frío, esa expresión cuasi pleonástica de la "ausencia sin olvido"; porque no hay olvido, la ausencia es.

Volviendo a la analogía con la plástica, Huerta emplea la palabra desde sus raíces de significación, dibuja con ella; también relaciona sus significados en un segundo y tercer plano. Semejante a la paleta del pintor que degrada los colores terciarios para obtener el matiz insólito, la poesía de Huerta ofrece una densidad semántica análoga a las veladuras y las transparencias obtenidas por los grandes maestros. No hay violencia sintáctica, su intención no es la creación de un sistema de significaciones inusitado, sólo ha profundizado en la degradación más sensible de los significados del lenguaje. Degradación en el sentido plástico del color, cuya virtud consiste en la aplicación rigurosa de la obtención del matiz deseado sin llegar al vacío, donde al matiz le exceda el blanco y aquél se pierde bajo el predominio de éste, donde ya no se dice nada, sino todo lo contrario, el verso henchido de significación. Aún cuando su poesía sea desagradable, en el contexto en que lo dice Solana, hay grandes analogías con el dibujo, donde a mayor 
escala de grises, hay mayor residencia como obra de arte: "Arenas, amargura, tierna vida en silencio", "vegetal ausencia", "Rayo de luna como pájaro solo", "un sueño sin premura por las venas", "las estrella / plateadas de cinismo", "la madera blanca como / castidad que aniquila", "Nubes y nubes no se sabe qué demonios terrestres aman o detestan / con su comportamiento de árboles desgajados", "Espectros de estertores / lanzados allá en el dorso de otros tiempos / por espinas ahogadas en los ríos, / por espejos y rosas transformados en prisa”.

Si la huella del surrealismo está presente en Los hombres del alba, sólo es un aspecto que determina a Huerta como un poeta de su tiempo. Eso no irá en detrimento de las grandes virtudes que lo han hecho un poeta de auténtica vanguardia.

La galaxia poética de Efraín Huerta está poblada por figuras protagónicas como la ciudad, el amor, las avenidas y, destaca sobre estas figuras, la del amor. El amor persiste. Efraín Huerter, hacia 1944, año en que se publica Los hombres del alba, tiene ya definido el arte poética que permeará la obra posterior. La publicación de ese año pasa a significar el eje de lo que será esa galaxia poética orquestada por la pasión del amor, la más humana de todas. Dirá más tarde, en Borrador para un testamento, hacia 1967: "He dicho siempre amor como quien todo / lo ha dicho y escuchado". Las convicciones ideológicas apuntadas arriba vienen a completar la postura humana de Huerta. Si de alguna manera podría relacionarse con la dialéctica universal de las grandes corrientes culturales, Huerta se asocia, más que a otra, a la romántica: anhelo de libertad, reflexiones ligadas al entorno, al hábitat; asombro y pasión por incursionar en las manifestaciones de la interioridad, la solidaridad humana, la reacción rabiosa en contra de lo establecido como origen de la vida pedestre. ${ }^{10}$ Corona todos estos estratos de

10 "Para los románticos había dos frentes que atacar en la organización social nacida de la Revolución Industrial: por un lado el capitalismo, que era la ex- 
la aventura de vivir, el amor, con todos sus matices, con toda su intensidad.

\section{Fuentes}

Blanco, José Joaquín, 1981, Crónica de la poesía mexicana, México, Colección Libro de bolsillo, Serie ensayo.

Cuesta, Jorge, 1994, "La nacionalidad mexicana", en Obras, t. II, México, El equilibrista.

Flores Flores, Ociel, 2008, "Efraín Huerta y Octavio Paz; dos trayectorias de la literatura social", Fuentes Humanisticas: 38, México, pp. 137-152.

Huerta, Efraín, 1944, Los hombres del alba, Rafael Solana (pról.), México, Géminis.

Lizalde, Eduardo, 1981, Autobiografia de un fracaso; el poeticismo, México, Martín Casillas-INBA.

plotación material del hombre por el hombre; y por otro el racionalismo, que era la opresión mental del hombre por el hombre" (Racionero, 1977: 27-28). Con un respaldo semejante, se comprende el desencanto de Huerta y el resultado de dejar atrás los poemas inspirados por el realismo socialista. Así pues, "el romanticismo no sólo fue un estilo lírico de expresión individual, sino también un movimiento cargado de intencionalidad de cambio social [...] el marxismo que por un lado combate las condiciones materiales del capitalismo, acepta por otra las condiciones mentales que hicieron posible ese capitalismo, que son el racionalismo cartesiano y el monopolio del conocimiento por el método científico [...] el marxismo no elimina la opresión mental del hombre por el hombre y en vez de conseguir una sociedad individualista, liberada y llena de diversidad, reproduce el mismo tipo mental masificado, conformista y no imaginativo del capitalismo" (Racionero, 1977: 29-30). Ante poemas como "Praga, mi novia" o "Cuba revelación", la tentación revolucionaria para Huerta se había desvanecido (vid. Flores, 2008: 145). La madurez, con sus emisarios comandados por los años de aprendizaje, ha desplazado a la inexperiencia, pero no al espíritu o ímpetu romántico. 
Pacheco, José Emilio, 1979, Antología de la poesía mexicana I; 1810-1914, México, Promexa.

Paz, Octavio, et. al., 1998, Poesía en movimiento, México, Siglo XXI.

Racionero, Luis, 1977, Filosofias del underground, Barcelona, Anagrama.

Solana, Rafael, "Prólogo", en Efraín Huerta, Los hombres del alba, México, Géminis, 1944, pp. 9-15.

Ylizaliturri, Diana, 1999, "Entrevista con Octavio Paz, editor de revistas", Letras Libres, julio, disponible en: www.letraslibres. $\mathrm{com} /$ revista/convivo/entrevista-con-octavio-paz-editor-de-revistas (consultado el 8/V/2014).

(Artículo recibido el 8 de mayo de 2014; aceptado el 22 de julio de 2014) 